This is a pre-print. Please cite the final version, published in Philosophy and Phenomenological Research 95, no. 3, 2017, 709-721

https://doi.org/10.1111/phpr.12435

\title{
Love and the Moral Error Theory: Is Love a Mistake?
}

Simon Keller, Philosophy and Phenomenological Research

\section{Could love be mistaken?}

Suppose that when you love someone, you take yourself to have reasons to treat her differently from others. If a good friend is in town, for example, you might feel that you should invite her to stay with you, even though you would not make the same offer to a stranger. Suppose further that the special reasons you take yourself to have, in loving someone, are objective reasons: reasons that do not follow straightforwardly from your desires and other subjective attitudes. ${ }^{1}$ You might think that you should invite your friend to stay with you whether it suits you or not, and whether or not it will get you something you want. Suppose finally that there are in fact no objective reasons; suppose that all your real reasons come from your subjective attitudes, none from anywhere else.

Those are controversial claims to suppose, but they each have their defenders. Many philosophers say that loving someone involves taking yourself to have special reasons of love, some of which turn out to be objective reasons (Velleman 1999; Scheffler 2001, pp. 100-101, 121-122; Kolodny 2003, pp. 146153; Jeske 2008, p. 63; Jollimore 2011, pp. 25, 71-72; Keller 2013, chh. 4-5). Some philosophers are moral error theorists, moved by the argument from

\footnotetext{
${ }^{1}$ From now on, when I talk about "desires," I mean to talk about all of a person's subjective states that contribute to motivation, including her values, preferences, goals, and projects. I will talk later about what it means for reasons to emerge "straightforwardly" from such states.
} 
queerness: they say that morality requires objective reasons, and that in fact there are no such things (Mackie 1977, pp. 38-42; Hinckfuss 1987, chh. 1-2; Garner 1990; Joyce 2001, chh. 1-5; Olson 2014, ch. 6).

If those all those claims are correct, then in loving another person you make a kind of mistake: you posit reasons that are not really there. It is conceivable, to that extent, that love is mistaken.

I will argue that the moral error theory, as supported by the argument from queerness, indeed implies that love is a mistake, and that this is bad news for the error theory. I will start by describing the views and arguments offered by recent moral error theorists, then I will argue that love sometimes posits objective reasons, and then I will say why the moral error theory leads to a moral error theory of love. Then I will say why this result counts against the moral error theory: it strengthens a major objection to the moral error theory and it shows the theory's practical consequences to be more troubling than its defenders allow.

\section{The moral error theory}

The argument from queerness

According to the moral error theory, ordinary moral judgments judgments like "torture is wrong" and "there is a moral duty to tell the truth" are all mistaken. ${ }^{2}$ The moral error theory is often explained by analogy with

\footnotetext{
${ }^{2}$ These are "first-order," "substantive" moral judgments. See Mackie 1977, pp. 9, 16; Joyce 2001, p. 6; Sinnott-Armstrong 2006, pp. 34-37; Olson 2014, pp. 12-15. Joyce \& Kirchin (2010, pp. xi-xii) give reasons why the moral error theorist should say that such moral judgments are "untrue", rather than "false." See also Garner 1990, pp. 137, 139-140; Burgess 2010, p. 8. For my now it is enough to
} 
atheism (Joyce \& Kirchin 2010, p. x; Burgess 2010, pp. 7-8; Kirchin 2012, pp. 7879). The atheist says that we always make a mistake when we talk about what the gods are like or what God commands, because there are no gods. The moral error theorist says that we always make a mistake when we say that something is morally right or wrong, because there are no such things as moral rightness and wrongness.

By far the most prominent argument for the moral error theory is the argument from queerness. ${ }^{3}$ It says that moral judgments can only be correct if the world contains certain evaluative entities, and that such entities, seen for what they are, are too strange to be real (Joyce \& Kirchin 2010, pp. xvi-xvii).

The label "argument from queerness" originates with J. L. Mackie. Mackie says that morality requires "objective values" or "objective prescriptions," by which he means values or prescriptions that exert normative force upon us independently of our motives (1977, pp. 29, 38. See also Olson 2014, chh. 5-6). Objective values and objective prescriptions, Mackie says, "would be entities or qualities or relations of a very strange sort, utterly different from anything else in the universe" (1977, p. 38). The most reasonable conclusion, he says, is that such things do not really exist, and hence that morality is systematically mistaken.

Other moral error theorists give different descriptions of the special entities that morality requires. Richard T. Garner (1990, pp. 137,143) says that morality requires "intrinsic imperativeness," Richard Joyce (2001, chh. 1-5, see

note that the moral error theorist thinks such judgments mistaken, in one way or another.

${ }^{3}$ Olson $(2014$, p. 3$)$ says that the argument from queerness is "central to the debate about moral error theory and about metaethics at large." 
especially p. 42) that it requires "external reasons," and Jonas Olsen (2014, ch. 6, see especially p. 118) that it requires "irreducibly normative reasons"; and they each argue that the relevant entities are objectionably strange. ${ }^{4}$ Their shared conviction is that the universe contains no intrinsic normativity. They all say that nothing can give us genuine reasons apart from our own subjective motivational states.

In making the argument from queerness, the moral error theorist needs to say not only that the objectionable entities do not exist, but also that morality cannot be vindicated without them. On the moral error theory, we cannot explain the moral wrongness of torture, for example, by saying that torture offends against our subjective values or our natural feelings of human sympathy, or does not accord with our higher-order or informed desires, or does not fit with our reflective self-conceptions or with the way we do things around here (Mackie 1977, chh. 2-7; Joyce 2001, chh. 3-4). If we can derive genuine moral truths from ordinary human attitudes or institutions, then the argument from queerness fails.

The argument from queerness may have consequences beyond morality. Perhaps it is not only morality that turns out to be mistaken if there are no objective reasons (Mackie 1977, p. 39; Kirchin 2014, p. 97; Olson 2014 p.3, ch. 8). One widely discussed possibility is that epistemic reasons - reasons to believe have the same structure as moral reasons, and that they too would be ruled out by the argument from queerness (Cuneo 2007; Streumer 2013; Olson 2014, pp.

\footnotetext{
${ }^{4}$ Joyce also describes the objectionable entities as "reasons that cannot be evaded" (2001, p. 100), and says that the trouble with morality is that it requires "inescapable practical authority" (2006, pp. 192-194). See also the list in Olson 2014, p. 117.
} 
155-172). The "companions in guilt" objection to the moral error theory says that the moral error theory looks less plausible, and is perhaps impossible to argue for or believe, once we see what else must be mistaken if the moral error theory is correct (Cowie 2014; Das 2017; Cuneo 2014).

\section{Practical consequences}

It is easy to think that the practical consequence of the moral error theory is chaos. If morality is one big mistake, we might think, then we are free to act like monsters. But most defenders of the moral error theory are quick to dismiss this suggestion, saying that nothing much about our behavior would or should change once we accept the moral error theory, and indeed that any change would probably be for the better.

For a start, moral error theorists often say that we do not need morality to find good reasons to treat each other well. Richard Joyce and Simon Kirchin (2010, p. xiv) say that "there are no grounds for thinking that the moral error theorist must be a sociopathic cad"; "her skepticism does not (in any obvious way) exclude the possibility of her being motivated by compassion, love, and altruism. John Burgess (2010, pp. 11-12) says that the moral error theorist can have "personal ideals and standards without the intellectual baggage of moral belief that usually accompanies them" (see also Joyce 2006, p. 224; Garner 2010, p. 219). As well as giving us non-moral reasons to treat each other well, runs the idea, love and compassion and personal ideals can inform the moral error theorist when he asks what we should do with moral thought and language, having noticed that they are mistaken. 
Some moral error theorists are "eliminativists," saying that we have good non-moral reasons to abolish moral thought and moral language. Without morality, they suggest, we would be less judgmental and better able to compromise (Hinckfuss 1987, ch. 5; Garner 2010; Burgess 2010, p. 12). Others are "preservationists," saying that morality, though mistaken, should be retained. They say that a shared moral sensibility can help us to exercise self-control, and can allow us to gain the benefits of mutual trust and cooperation (Mackie 1977, pp. $106,108,235$; Joyce 2001, pp. 180-185, ch. 8, pp. 206-215; Joyce 2006, pp. 227-228; Olson 2014, pp. 181, 195-196. See also Nolan, Restall, \& West 2005, pp. 310-314).

Among preservationist moral error theorists, some recommend that we take morality sincerely in our everyday lives and pay attention only in philosophical moments to the fact that it is mistaken (Olson 2014, pp. 190-196). Others advocate versions of "moral fictionalism," saying that we can have moral beliefs and make moral assertions without taking them literally; we could think of ourselves as engaged in pretense, or as thinking and talking about what is (truly) the case according to a (false but useful) fiction (Joyce 2001, pp. 185-205, 214-221; Nolan, Restall, \& West 2005, pp. 308-310).

Those, then, are some of the main arguments and positions in the debate about the moral error theory. I will return to them after talking about the reasons of love.

\section{$\underline{3 .}$ Reasons of love}

The question 
Love comes in many varieties; there is erotic love and there is love of chocolate. When philosophers discuss the reasons of love, they have in mind the kinds of love found within healthy, loving, intimate personal relationships. They ask what reasons of love exist between good friends and long-term romantic partners, and between parents and children and siblings within a close and caring family (Kolodny 2013, p. 137).

Reasons of love, if they exist, are special reasons. They are agent-relative; your reasons of love are different from mine, because you and I have loving relationships with different people. And they are discriminating; a reason of love is a reason to treat one person differently from other people.

It is one thing to ask whether we have certain reasons of love, and another to ask whether in loving we take ourselves to have certain reasons of love. For now, I want to ask the second question: what reasons, if any, do you take yourself to have, when you love someone?

Why believe in reasons of love?

In a case famously discussed by Bernard Williams (1981, pp. 17-19), a man must choose whether to save his wife or a stranger. Perhaps the man is standing on a pier, with his wife drowning on one side of the pier and the stranger drowning on the other, and with time to save only one of them. Moved by his love for his wife, the man saves her, in preference to the stranger. Williams' interest is in the man's motivating thoughts. What considerations will move the man to save his wife, and what does this tell us about the special reasons he takes himself, in loving his wife, to have? 
It is possible to be motivated to do something without taking yourself to have any reason to do it. If you have ever had the urge to giggle at an inappropriate moment during a funeral, that motive probably struck you as a mere urge, carrying nothing to recommend it. Your response was probably to try to make the urge go away. The loving husband, in contrast, will not experience his motive to save his wife as a mere urge, which he could just as well resist. In his eyes, the fact that his wife's life is at stake means that he should save her. If he finds his motive waning - perhaps it is confronted by his aversion to getting wet - then he will, if he loves his wife, try to restore his motive and make sure that it drives him to action. That suggests that he takes his motive to be supported by good reasons, and more generally, that in loving we take ourselves to have special reasons of love, of one kind or another (see also Kolodny 2013, pp. 135, $137,142-146)$.

\section{Subjective or objective reasons?}

Williams says that the husband's motivating thought will be something like "That's my wife!" and he takes this thought to refer to the husband's "ground projects" (1981, pp. 12-19; see also Keller 2013, pp. 11-23). A ground project is a commitment that helps constitute a person as a distinct agent; our selfconstituting commitments to the people we love, Williams suggests, are the grounds of our reasons of love. Harry G. Frankfurt (2004, especially p. 46) offers a similar view, saying that love produces reasons because it is a kind of caring that places constraints on the will. Common to Williams and Frankfurt is the suggestion that we find reasons of love to emerge from our deepest 
commitments. We experience our reasons of love, on this view, as subjective reasons.

Most philosophers in the recent literature on love take a different view, saying that reasons of love, as we posit them, are sometimes objective.

On one story, the experience of loving someone is an experience of appreciating and responding to her special value, which would be there whether you noticed it or not. J. David Velleman (1990, pp. 344-348, 360-362) says that in loving a person you become vulnerable to her incomparable value as an autonomous agent, and find her value to generate reasons for you to respond to her directly, without comparing her with others (see also Keller 2013, pp. 139144).

An alternative view says that we find reasons of love in the significance of our loving relationships. Diane Jeske (2008, chh. 2-4 and p. 63) says that we treat intimate relationships as fundamental, objective, agent-relative reasons, so that "He's my friend" is in itself a reason for you to give your friend special treatment (see also Scanlon 1998, pp. 161-162). Niko Kolodny (2003, pp. 146-153) says that to love someone is to take your relationship with her to have final value, which in turn is to take yourself to have reasons to treat her differently from others (see also Scheffler 2001, pp. 100-101, 121-122). The idea is that we take our relationships to generate reasons in their own rights, not just because we value or care about them.

On views like these, we take ourselves to have reasons of love that are not grounded in our subjective attitudes. Love, however, is itself a subjective state; to love someone is to have certain attitudes and feelings. So how could reasons of love be objective reasons? 
For one thing, a subjective attitude can posit objective reasons. The belief that torture is wrong, for example, is a subjective attitude, but it (arguably) posits objective reasons, and only gets to be true if objective reasons exist. Perhaps love is relevantly similar.

Also, it may be that you need to have certain subjective attitudes to come to have certain objective reasons. Perhaps you need to love someone in order to perceive her special value, but perhaps that value, once you perceive it, generates reasons for you directly. Perhaps you need to love someone in order to forge a valuable intimate relationship with her, but perhaps that relationship, once it exists, generates special reasons independently of your ongoing attitudes. The historical story about why you have reasons of love could be a story about your attitudes, even if the story about the nature of the reasons is not.

It is an open question, then, whether reasons of love, as we posit them in loving, are subjective or objective. I want to offer three arguments for thinking that at least some of them are objective.

\section{First argument: love and obligation}

Sometimes, in loving someone, you take yourself not only to have special reasons, but also to have special obligations (Raz 1989, p. 19; Scheffler 2001, pp. $50,100,121-122)$. Imagine that you discover that people are plotting behind your friend's back. You may well feel that if the victim of the plot were a stranger, then you would be entitled to stay out of it, but that when it is your friend, you have an obligation to tell him what is happening, even if doing so will involve risk and discomfort for you. Many other kinds of love also involve taking yourself to have special obligations of love. It would be odd to say that you love your child or 
parent, or someone with whom you share a long-term romantic relationship, while also saying that you do not owe him anything more than you owe people generally.

When you posit an obligation to do something, you posit a reason to do it. A reason corresponding to an obligation of love will be an objective reason. Your reason to tell your friend about the plot will not strike you as emerging from your desires; you hold the obligation to your friend, not to yourself. To fail to tell your friend about the plot would be to let him down, not (or not only) to let yourself down. Only he could relieve you of the obligation, and only he could forgive you if you fail to meet it. In taking yourself to have an obligation of friendship, you take your friend to have a special claim against you, because you are his friend. Your obligation of friendship, as it strikes you, is grounded in his rights and interests, not in your subjective attitudes.

\section{Second argument: love and sacrifice}

Love often involves a preparedness to make sacrifices, conceptualized as sacrifices. Imagine a future in which your husband becomes very sick and requires your constant care. Imagine that caring for him will require you to sacrifice professional opportunities, leisure pursuits, and other relationships, and will not be very rewarding; mostly, it will be menial and unpleasant. Considering this possibility, you may well feel that looking after your husband would not give you the life you most want and value. It would mean sacrificing your own goals and projects for the sake of your husband. Yet if you love him, then you will feel that you have reason to make the sacrifice. 
Imagine a future in which your child becomes a criminal and exploits your concern for her. Imagine that looking after her means regularly collecting her from the police station, lodging her bail, and allowing her to live with you even as she abuses your trust. Imagining such a future, if you love your child, you will not stand ready simply to abandon her. But neither will you imagine sticking by your child as the course of action that lets you live out your own hopes and dreams. If it were just your goals and projects at stake, you might think, then you would leave your child to take care of herself.

On one way of looking at it, in being prepared to make sacrifices of love you stand prepared to sacrifice some of your desires for others. You might prioritize your commitment to your husband or child over your other commitments. But that description, while correct as far as it goes, does not capture the full nature of the sacrifices you are prepared to make. It is not just that you care more about the person you love than about other things; it is not just that you would prefer to stick by your sick husband or your criminal child than to do other things with your life. What you are prepared to sacrifice, for the sake of the person you love, is yourself.

To be prepared to make sacrifices of love, then, is to place yourself in the service of something that matters beyond yourself. You treat your reason to make sacrifices as a reason that comes from outside: a reason, in the cases, that might come from the value of your husband's humanity, or from the importance of the parent-child bond. Your reasons to make sacrifices of love, as you posit them, are objective. 
Sometimes we take ourselves to have very demanding reasons, grounded in our own desires and projects. Consider a variation of the case of the man on the pier.

Suppose that you have been working for years on your dissertation, and as you finish making the final changes, your computer crashes and its memory is destroyed. Fortunately, you have saved your dissertation to a memory stick just in time, and now you are off to the university to submit it. On the way, you go for a walk along a pier, and you accidentally drop the memory stick into the water on one side of the pier. On the other side of the pier, another student, who has also just completed her dissertation and who also has only one saved copy, drops her memory stick into the water at just the same time. You can swim, and the other student cannot. You have time to save your dissertation or the other student's dissertation, but not to save both.

You may well choose to save your own dissertation. In doing so, you might possibly be moved by thoughts of how much wisdom will be lost to the world if the dissertation is not submitted. It is more likely, though, that in saving your dissertation you will be moved by thoughts of yourself. As the memory stick sinks into the water, you will see sinking with it all the hard work you have put into your dissertation. You will think of how much you have invested in the dissertation, of the years of your life that will be wasted if it is not recovered, of how much of you the dissertation contains.

Alternatively, you might decide to save the other student's dissertation. Imagine her reaction, and the reaction of others, if you did. She will be enormously, eternally grateful. People may praise you as a hero. Your act would be astonishingly generous. In saving her dissertation rather than your own, you 
put her interests above yours. You give up something of great importance to you so that she may have something of great importance to her.

Now suppose that as you stand on the pier it is not your dissertation but your wife who needs saving, while a stranger drowns on the other side of the pier. Suppose that you jump in and save your wife, moved by the sorts of thoughts that would drive you to save your dissertation. Suppose that you are moved by thoughts of all the work that you have put into your marriage and of the part of your life that will be lost if your wife is no longer around; suppose that you are moved to save your wife by your concern with protecting your investment. In saving your wife out of considerations like these - in acting for reasons you conceive as subjective - you are not moved by motives of love: not love for her, anyway (Keller 2013, pp. 41-43).

Imagine now that you choose to save the stranger, in preference to your wife. The person you save, and the people who love him, would be pleased, and probably grateful. But you would not look like a hero, and your act would not look like an act of generosity. You would look instead like someone who does not love her wife.

What reasons we take ourselves to have is sometimes revealed in the character of our motives. And in some central cases, the character of our motives of love suggests that we take our reasons of love to be objective.

Those are my arguments for saying that love posits objective reasons. ${ }^{5}$ (And let me stress again that this is the view defended in most recent work on the reasons of love.) What follows for the moral error theory?

\footnotetext{
${ }^{5}$ For further arguments, see Jeske 2008, pp. 31-35; and Velleman 1999, especially pp. 351-354.
} 


\section{$\underline{4 .}$ Love and the error theory}

\section{An error theory of love}

According to moral error theorists who accept the argument from queerness, the problem with morality is that it depends upon the existence of strange normative entities: entities that would have authority over us independently of any connection with our desires. If love posits objective reasons, then in the eyes of moral error theorist, love will look mistaken too, and there will be reason to offer an error theory of love.

Love cannot be mistaken in the same respect in which a false belief is mistaken; love is not the kind of state that can simply be false. Instead, love would be mistaken in the respect in which an emotion can be mistaken. ${ }^{6}$ The mistake involved in love, given that there are no objective reasons, would be like the mistake involved in fearing kittens, given that kittens are not dangerous. The form taken by an error theory of love will depend on how that mistake is explained, and in particular on how exactly love "posits" or "takes there to be" objective reasons.

One possibility is that love takes there to be objective reasons because love involves believing yourself to have certain reasons, which turn out to be objective. On cognitivist views of the emotions, emotions can be partly constituted by beliefs (Nussbaum 2001, ch.1; Solomon 2004, p. 83; Goldie 2000, p. 48). An emotion can then be mistaken because the beliefs it incorporates are

\footnotetext{
${ }^{6}$ Solomon (1981, ch. 4-5), Velleman (1999), and Goldie (2000, p. 14) explicitly take love to be an emotion. See also Kolodny 2003, p. 137. For my purposes, it is enough to say that love, whatever it is, can conceivably be mistaken in the same way in which an emotion can be mistaken.
} 
false; fear of kittens might be mistaken because it incorporates the false belief that kittens are dangerous. An error theory of love could say that love is mistaken because it incorporates false beliefs about reasons.

Another possibility is that love takes there to be objective reasons by presenting a picture on which there are such reasons - whether that picture is expressed in our beliefs or not. Philosophers sometimes compare emotions with perceptions. ${ }^{7}$ Your perceptions can present a picture that you do not accept; you can see things as being a certain way while knowing you are under an optical illusion. Similarly, you can find yourself fearing kittens even while knowing that kittens are not dangerous; perhaps the right thing to say about such a case is that your fear of kittens presents kittens as dangerous, even as you know that they are not. A second version of the error theory of love could say that love is mistaken because it presents an inaccurate picture of the world: a picture on which the world contains objective reasons.

As another possibility, love could take there to be objective reasons by involving feelings and dispositions that only make sense if objective reasons exist. Think about what it would be like to fear kittens while knowing that kittens are not dangerous. You might panic when you see a kitten, and you might flinch and want to flee when a kitten moves toward you. That will be embarrassing. ${ }^{8}$ It makes no sense to have such feelings and dispositions in response to something that will do you no harm. Fear of kittens can make life

${ }^{7}$ D'Arms \& Jacobson (2000, p. 67) say that emotions involve "evaluative presentations." See also Smith 2002, pp. 112-113; de Sousa 2004, p. 73; Prinz 2004a, ch. 3; Prinz 2004b, especially pp. 45, 54-56.

${ }^{8}$ D'Arms \& Jacobson (2000, p. 67) speak of the "unstable position of feeling an emotion while resisting its evaluative presentation.". 
more difficult; considering the truth about kittens, it is an emotion you might want to get over, if you can.

If you love someone, then you will feel that you have special obligations towards her, you will be disposed to make sacrifices of love, and you will have motives whose quality indicates that you have reasons that exist independently of your own desires. If you also believe that there are no objective reasons, and you think about it too carefully, then those feelings and dispositions will not make much sense to you. When they stand as obstacles to your living out your own hopes and dreams, you may see them as feelings and dispositions to get over, if you can. So there is a third version of the error theory of love, which does not make claims about what we believe or how we see things, when we love. It says that love is mistaken because it involves feelings and dispositions that make no sense, given there are that no objective reasons.

There are then at least three different versions of the error theory of love. But if I am right in arguing that love takes there to be objective reasons, in one way or another, then a moral error theorist needs to adopt an error theory of love, of one version or another.

\section{Resisting the error theory of love}

Objective reasons, I have said, are reasons that do not follow "straightforwardly" from an agent's subjective motivational states. The moral error theorist could resist the move to an error theory of love by saying that reasons of love, as we posit them, are indeed grounded in our subjective attitudes, even if not in a straightforward manner. Your reasons of love might be explained as emerging from your higher-order desires, or the desires of your 
deepest or true self, or the desires you would have if you were fully informed and rational. Or they could be grounded in values you project or create. Or they could be facts about what it takes for you to play a certain social role. Or perhaps they can be reduced in some other way to unremarkable facts about the natural or social world. If some such story can be told, then reasons of love might not require the kinds of entities that the moral error theorist finds objectionable.

That response, however, will not sit comfortably with the moral error theorist's other commitments. Its strategy for explaining (what look like) objective reasons of love will be one that the moral error theorist rejects when it comes to explaining the (purported) objectivity of morality. The problem with morality, according to the argument from queerness, is that it posits a kind of normative power that ordinary natural and social entities cannot provide. But that is just the kind of power claimed by reasons of love. When the moral error theorist tells a story about how to reduce reasons of love to unobjectionable psychological or social facts, he lends us a template for an equally convincing story about how to reduce moral reasons to facts of the same kind, and the argument from queerness loses its force. ${ }^{9}$ So I do not think that this is a promising line of response for the moral error theorist.

\section{Companions in guilt}

The moral error theory, by my argument, leads to an error theory of love. That adds extra bite to the "companions in guilt" objection: the objection that the

\footnotetext{
${ }^{9}$ Michael Smith (2017, see especially pp. 146-147) seeks to explain reasons of love as grounded in certain privileged desires. It is important to Smith's account, though, that his explanation of reasons of love fits neatly with a broader naturalistic account of reasons, including moral reasons.
} 
moral error theory, as supported by the argument from queerness, has unacceptable implications for things other than morality.

It is difficult to believe that nothing is morally right or wrong. It is even more difficult to believe in addition that when you are taken by love - when you look lovingly into the eyes of your partner and when you are moved to make special sacrifices for the sake of your child - you are in the grip of a mistake.

The moral error theory, that is to say, has intrusive and implausible implications beyond its claim about morality; and this remains true even if the moral error theorist can find a way to avoid skepticism about epistemic reasons. The connection between the moral error theory and error theories of love gives an extra reason to go back to the argument from queerness and ask whether something has gone wrong. It gives an extra reason to look for an account of objective reasons that does not commit us to the existence of queer entities, or to decide that if we need to posit queer entities to save both morality and love, then that is a price worth paying. ${ }^{10}$

\section{Practical consequences of the moral error theory, again}

Moral error theorists say that we have non-moral reasons to treat each other well: non-moral reasons to engage in (what we might previously have regarded as) moral behavior. They say that we can be moved by reasons of love, compassion, and altruism, and by personal ideals.

${ }^{10}$ Enoch (2011, pp. 267-271) defends moral realism, and the ontological investment it involves, by "tallying plausibility points". 
Reasons of love, however, turn out to be just as problematic as moral reasons, in the eyes of the moral error theorist. That takes away one source of reasons, by the error theorist's lights, to continue as we were.

The problem is not just that we need to remove reasons of love from the list of respectable reasons. It is also that once we see that love posits objective reasons, it is easy to suspect that the same is true of compassion, altruism, and personal ideals. What is compassion, and what is altruism, if they do not involve taking others' interests to matter, and to generate reasons, in their own rights? What is a personal ideal, if it does not involve finding something beyond yourself to be valuable and to give you reasons? Obviously these are further questions, but they become crucial questions for the moral error theorist once the error theory's implications for love are understood. It is not enough to say that we can find non-moral reasons to treat each other well. The moral error theorist also needs to show that such reasons, as we find them, are subjective. In the case of reasons of love, at least, they are not.

\section{Practical consequences of the error theory of love}

The moral error theorist needs to ask what we should do with love, having noticed that it is mistaken. As with morality, the choice is whether to recommend that love be eliminated, or instead that love, though mistaken, should be preserved.

Eliminativism about love does not look attractive. Surely you could not stop loving your friends and your children even if you tried, and surely the trying would make your life horrible. There might be some reason to think that the world would be better without morality, but it is difficult to see how the world 
would be better without love. Perhaps the best version of eliminativism about love would be relatively moderate. Rather than telling you to rid yourself of all traces of love, we could recommend that you do your best to suppress those aspects of love that involve your taking there to be objective reasons. When love gets in the way of your thoroughly subjective goals, we might advise you to try to get over it.

The other option is to recommend that we keep love alive. To some extent, this recommendation will be supported by considerations of prudence. Your life would be worse if you did not enjoy intimate loving relationships, so it is in your best interests to maintain such relationships, even if that requires you to posit reasons that are not really there.

The challenge for the option of preserving love, though, is to say how you could genuinely love someone while being aware that in doing so you are seeing things wrongly. A self-consciously fictionalist attitude towards reasons of love does not look consistent with love. To save your wife from drowning because there is a false but useful fiction according to which you have special reasons to save her: that does not sound like an act of true love. Perhaps you could embrace your attitudes of love in everyday circumstances, remembering only in philosophical moments that they are misguided. In those philosophical moments, though, you will evaluate your attitudes of love by asking whether they serve your subjective reasons. Even the tendency to engage in such self-centered reflection in philosophical moments, plausibly, is inconsistent with genuine love.

The point, in any event, is that the error theory of love raises a new and difficult practical question, and in answering it, the error theorist will need to recommend far-reaching changes to the ways in which we relate to ourselves 
and others. Loving relationships will need to be abandoned, or altered, or rethought, or regularly questioned; or we will need to pretend that we have objective reasons of love and then forget that we are pretending. We cannot go on much as we were.

\section{$\underline{\text { 5. Conclusion }}$}

By my arguments here, love posits objective reasons, relevantly similar to moral reasons, so the moral error theorist, where moved by the argument from queerness, needs to accept an error theory of love. This shows the moral error theory to be more theoretically and practically radical than error theorists themselves acknowledge.

Nothing in my argument proves the moral error theory false. I have not defended an alternative account of the nature of morality and I have not said much about where the arguments for the moral error theory might go wrong. If a moral error theorist accepts that love is a mistake, and accepts the consequences that follow, no problem. But in accepting those consequences, the moral error theorist will make claims that existing moral error theorists are eager to avoid.

This paper is about the moral error theory. I have argued that love posits objective reasons, but I have tried to avoid choosing between the different stories about what those objective reasons are. A more precise view about what reasons are posited by love might generate arguments that apply to other theories in metaethics. Whether a metaethical theory can make room for reasons of love might depend on whether it can make room for irreducibly agent-relative obligations, or for relationships that stand as reasons in their own rights, or for the incomparable value of individual agents - depending on what is needed for 
reasons of love, as we posit them, really to exist. Speaking broadly, there is a connection between the nature of love and the nature of values and reasons, and that connection may produce surprising results for views beyond the moral error theory. ${ }^{11}$

\section{REFERENCES}

Burgess, J. P. (2010). “Against Ethics.” in R. Joyce \& S. Kirchin (eds.) A World Without Values: Essays on John Mackie's Moral Error Theory (pp. 1-15). Dordrecht: Springer.

Cowie, C. (2014). "Why Companions in Guilt Arguments Won't Work." The Philosophical Quarterly 64(256), 407-422.

Cuneo, T. (2007). The Normative Web: An Argument for Moral Realism. Oxford: Oxford University Press.

Cuneo, T. (2014). Speech and Morality: On the Metaethical Implications of Speaking. Oxford: Oxford University Press.

D’Arms, J., \& Jacobson, D. (2000). “The Moralistic Fallacy: On the 'Appropriateness' of Emotions." Philosophy and Phenomenological Research 61(1), 65-90.

Das, R. (2017). “Bad News for Moral Error Theorists: There Is No Master Argument Against Companions in Guilt Strategies." Australasian Journal of Philosophy 95(1), 58-69.

\footnotetext{
${ }^{11}$ Nicky Drake provided very helpful research assistance and feedback in the writing of this paper. I also benefited from questions and comments from several people, including Derek Baker, Ramon Das, Luara Ferracioli, Michael Gilchrist, Richard Joyce, Jeanette Kennett, Simon Kirchin, Philip Pettit, Michael Smith, Justin Sytsma, and Nic Southwood.
} 
de Sousa, R. (2004). “Emotions: What I Know, What I'd Like to Think I Know, and What I'd Like to Think." in R. C. Solomon (ed.), Thinking About Feeling (pp. 61-75). Oxford: Oxford University Press.

Enoch, D. (2011). Taking Morality Seriously. Oxford: Oxford University Press. Frankfurt, H. G. (2004). The Reasons of Love. Princeton: Princeton University Press.

Garner, R. (1990). "On the queerness of moral properties and facts.” Australasian Journal of Philosophy 68(2), 137-146.

Garner, R. (2010). “Abolishing Morality.” in R. Joyce \& S. Kirchin (eds.) A World Without Values: Essays on John Mackie's Moral Error Theory (pp. 217-233). Dordrecht: Springer.

Goldie, P. (2000). The Emotions: A Philosophical Exploration. Oxford: Oxford University Press.

Hinckfuss, I. (1987). The moral society: Its structure and effects. Canberra: Australian National University.

Jeske, D. (2008). Rationality and Moral Theory. New York: Routledge.

Jollimore, T. (2011). Love's Vision. Princeton: Princeton University Press.

Joyce, R. (2001). The Myth of Morality. Cambridge: Cambridge University Press.

Joyce, R. (2006). The Evolution of Morality. Cambridge, MA: MIT Press.

Joyce, R., \& Kirchin, S. (2010). “Introduction.” in R. Joyce \& S. Kirchin (eds.) $A$ World Without Values: Essays on John Mackie's Moral Error Theory (pp. ixxxiv). Dordrecht: Springer.

Keller, S. (2013). Partiality. Princeton: Princeton University Press.

Kirchin, S. (2012). Metaethics. Basingstoke: Palgrave MacMillan. 
Kolodny, N. (2003). “Love as Valuing a Relationship.” The Philosophical Review 112(2), 135-189.

Mackie, J. L. (1977). Ethics: Inventing Right and Wrong. London: Penguin Books.

Nolan, D., Restall, G., \& West, C. (2005). "Moral fictionalism versus the rest.” Australasian Journal of Philosophy 83(3), 307-330.

Nussbaum, M. C. (2001). Upheavals of Thought: The Intelligence of Emotions. Cambridge: Cambridge University Press.

Olson, J. (2014). Moral Error Theory: History, Critique, Defence. Oxford: Oxford University Press.

Prinz, J. J. (2004a). Gut Reactions: A Perceptual Theory of Emotion. Oxford: Oxford University Press.

Prinz, J. J. (2004b). “Embodied Emotions.” in R. C. Solomon (ed.), Thinking About Feeling (pp. 44-58). Oxford: Oxford University Press.

Raz, J. (1989). “Liberating Duties.” Law and Philosophy 8(1), 3-21.

Scanlon, T. M. (1998). What We Owe to Each Other. Cambridge, MA: Harvard University Press.

Scheffler, S. (2001). Boundaries and Allegiances. Oxford: Oxford University Press. Sinnott-Armstrong, W. (2006). Moral Skepticisms. Oxford: Oxford University Press.

Smith, B. C. 2002. "Keeping Emotions in Mind.” in P. Goldie (ed.), Understanding Emotions (pp. 111-121). Aldershot: Ashgate.

Smith, M. (2017). “The 'What' and 'Why' of Love's Reasons.” in E. E. Kroeker \& K. Schaubroeck (eds.), Love, Reason and Morality (pp. 145-162). New York: Routledge. 
Solomon, R. C. (1981). Love: Emotion, Myth and Metaphor. Garden City, NY: Anchor Press.

Solomon, R. C. (2004). “Emotions, Thoughts, and Feelings: Emotions as Engagements with the World." in R. C. Solomon (ed.), Thinking About Feeling (pp. 76-88). Oxford: Oxford University Press.

Streumer, B. (2013). "Can We Believe the Error Theory?" Journal of Philosophy $110(4), 194-212$.

Velleman, J. D. (1999). “Love as a Moral Emotion.” Ethics 109(2), 338-374.

Williams, B. (1981). Moral Luck. Cambridge: Cambridge University Press. 